\title{
Accounting
}

\section{The impact of CEO duality on firm performance: Examining the life-cycle theory in Vietnam}

\author{
Duc Huy Phama* and Quoc Viet Phama
}

\begin{tabular}{|c|c|}
\hline CHRONICLE & A B S T RACT \\
\hline $\begin{array}{l}\text { Article history: } \\
\text { Received March } 102020 \\
\text { Received in revised format March } \\
152020 \\
\text { Accepted June } 102020 \\
\text { Available online } \\
\text { June } 122020\end{array}$ & $\begin{array}{l}\text { We examine the impact of CEO duality on firm performance using the life-cycle theory approach. The } \\
\text { data is balanced and covers over the period } 2012-2018 \text { for } 442 \text { publicly listed firms in Vietnam. The } \\
\text { findings from system generalized method of moments (GMM) method indicate that CEO duality had } \\
\text { a positive effect on firm performance in growth stage and had a negative effect on the mature stage of } \\
\text { the firm's life-cycle. These results are supported by stewardship theory which argues that CEO duality } \\
\text { may be good for firm performance in the growth stage due to the unity of presented command. In }\end{array}$ \\
\hline $\begin{array}{l}\text { Keywords: } \\
\text { CEO duality } \\
\text { Firm performance } \\
\text { The life-cycle theory }\end{array}$ & $\begin{array}{l}\text { contrast, agency theory shows CEO duality is bad for firm performance in the maturing stage since it } \\
\text { compromises the monitoring and controls the behavior of the CEO. Also, this study shows that there } \\
\text { was a difference between state shareholders and director from outside of the company affecting the } \\
\text { firm performance. }\end{array}$ \\
\hline
\end{tabular}

(C) 2020 by the authors; licensee Growing Science, Canada

\section{Introduction}

The vital roles of the CEO and chairman of the board in the companies are different (Doan, 2020). The CEO is responsible for managing and operating the firm, meanwhile the chairman is in charge of leading the board of directors. CEO duality takes place when one person serves both as a firm's CEO and board chair. There are two views about CEO duality, drawn from agency theory and stewardship theory, that are directly at odds with each other. Agency theory suggests that CEO duality will create a powerful CEO and then they use power to impede decisions and supervision of the board to the behaviour of them, which will affect the firm performance (Jensen \& Meckling, 1976; Muhammad et al., 2019). In contrast, stewardship theory argues that CEO duality establishes strong leadership ability by a unity of command, therefore, the leader may make better and faster decisions. Consequently, high self-determination will yield firm results (Donaldson \& Davis, 1991; Muth \& Donaldson, 1998; Bich \& Thai, 2019). Most previous studies did not consider the differential impact of powerful CEO on firm performance concerning the life-cycle of the firm. Cornett et al. (2008) supported the stewardship theory, saying that CEO duality often harms firm performance (Dalton et al., 1998; Fama \& Jensen, 1983). However, Yang \& Zhao (2014) reflects the viewpoint of stewardship theory, saying that CEO duality can run and supervise the firm clearly and consistently so that the firm performance can be increased to bring benefits of shareholder (Adams et al., 2005; Bhagat \& Bolton, 2008; Cadbury \& Cadbury, 2002).

\footnotetext{
* Corresponding author.

E-mail address: huypham@ufm.edu.vn (D. H. Pham)
} 
Empirically, previous studies about CEO duality have mostly mixed results and usually used representation theory or management theory as a theoretical background for their studies, but in the author's subjective view, there is almost no research to test two both this theory. To address this problem and to reconcile the opposite view of agency theory and stewardship theory, this study applies the life-cycle theory to test the effect of CEO duality has different on firm performance through the life-cycle of the firm.

In this article, we apply the life-cycle theory according to Anthony and Ramesh (1992) to reconcile agency theory and stewardship theory of CEO duality by assessing whether there is any difference about CEO duality in the life-cycle of the firm stage. We also examine whether CEO duality is beneficial to determine the future direction for growth when the firm is in the growth stage, while CEO duality is detrimental and the firm is in the mature stage or decline stage, at which it requires checkand-balance rather than power concentration. With the subjectivity uncovered, studies on CEO duality affect firm performance in the life-cycle of the firm.

\section{Theoretical background and hypotheses}

Firms, like products, go through various life-cycle stages: start-up, growth, maturity, and stagnation. Miller and Friesen (1984), Quinn and Cameron (1983) demonstrate the firms have common characteristics in each stage of the firm life-cycle and the difference between the life-cycle of firm stages is the complexity of the system of corporate governance and changing in resource demand (Jawahar \& McLaughlin, 2001). More recently, Li and Zhang (2018) investigated the relationship between the effects of the firm life- cycle on board structure, however, they did not examine the effects of board structure on firm performance at different life-cycle stages. Based on previous studies, the different life-cycle stages involve appropriate changes in the management of firms. For example, in the growth stage, investment in growth opportunities begins, and therefore strategies are constantly changing.

The CEO has a leading role to bring success to the company. We expect that change in CEO duality is more pronounced in the maturity stage, decline stage, and then affecting firm performance. In addition, Peng et al. (2007) justified their assumption that start-up companies (growth) are often owned and managed by founders (family members). Therefore, CEO duality will have a positive impact on firm performance because the firm is needed for proper direction and focus at this stage. This view is consistent with the stewardship theory (Donaldson \& Davis, 1991; Muth \& Donaldson, 1998) that CEO duality will support decision making, especially in urgent circumstances. However, companies will have more severe representation problems and less dependence on external resources in the maturity stage and decline stage than the growth phase. Therefore, the firm will reduce the need for resources and strengthen oversight in management to minimize representation issues between shareholders and managers, so that CEO duality will decrease the supervision role of the board of directors and negatively affect the firm performance. This view is quite close to the representative theory (Jensen \& Meckling, 1976) that CEO duality will negatively influence on firm performance. From these points of view, we propose the following hypotheses:

Hypothesis H1: In the growth stage, CEO duality has a positive impact on firm performance. Hypothesis H2: In the maturity stage and decline stage, CEO duality harms firm performance.

\section{Methodology}

\subsection{Sample}

The database used is taken from financial statements and governance reports of the firms listed on Vietnam's stock market (HOSE, HNX) from 2012 to 2018. This period marks the time of announcement Circular 121/2012 of the Ministry of Finance, which stipulates that the Chairman of the BOD will not concurrently hold the role of CEO unless it is approved at the annual general meeting of shareholders. The study also excluded financial sector companies from the sample because these companies often operated on a separate principle. Therefore, the data in this study consisted of 442 companies and 3,094 observations. According to Li \& Zhang (2018), Liang et al. (2011) a majority of publicly listed companies have gone through the start-up period. Therefore, we categorize them into three stages: growth, maturity, and stagnation. Multiple financial indicators and firm age are used to classify the firm-year observations into one of the three life-cycle stages. On average, sales growth, marketing expenditure, and capital expenditure are usually higher in the growth stage, forcing companies to apply more conservative dividend policies to keep more funds. However, in the stages of maturity and stagnation, capital and marketing expenditures gradually decrease, along with sales growth rates, enabling companies to pay higher dividends. Based on the discussion above, this study uses the classification method proposed by Anthony \& Ramesh (1992), Li \& Zhang (2018), Liang et al. (2011), along with marketing expenditure rates to determine life-cycle stages. Consequently, 600 firm-year observations are in the growth stage, 1,789 are in the maturity stage, and 705 are in the stagnation stage. 
Variables are coded based on prospectuses and annual reports. The previous studies all rely mainly on Tobin's q or return on assets (ROA) as a measure of firm performance (Adams et al., 2005; Duru et al., 2016; Singh et al., 2018). This study uses Tobin's q to proxy for firm performance. According to Singh et al. (2018), Tobin's q being a market-based measure of firm performance is also future-oriented, and therefore reflects the present value of future cash flows based on current and future information. The Independent variable is proxy CEO duality, If CEO duality can be identified (one person serves both as CEO and board chair), a dummy variable of 1 is used. Otherwise, it is 0 . Overall, CEO duality is found in 25.4 percent of firms (Table 1). Five control variables are employed: (i) state ownership; (ii) outside directors; (iii) firm size; (iv) risk and (v) debt. State ownership is important because all sampled firms are transformed SOEs, in which the state on average still holds approximately 43 percent equity (Table 2 ).

The relationship between state ownership and firm performance mixed. Therefore, state ownership is controlled. Outside directors, another control variable, are typically studied together with CEO duality in corporate governance research (Dalton et al., 1998). On the one hand, a firm that practices CEO duality is likely to have a smaller percentage of outside directors. However, a firm which splits the top two positions is more likely to have a strong, assertive board with a substantial presence of outside directors. Aside from the above-mentioned variables, we use the natural logarithm of total assets (Firm size), the liabilities to equity ratio (Debt) to control for firm size and leverage and business risk (Risk) is the risk arising when a company encounters liabilities in their operating activities which is measured by the standard deviation EBIT to total assets.

\section{Table 1}

Symbol and description of variables.

\begin{tabular}{lll}
\hline Variable & Symbol & Variable description \\
\hline Performance & Tobin's O & Ratio of market-to-book value \\
CEO duality & Duality & A dummy variable equal to one if the CEO is also the chairman of the board, and zero otherwise. \\
Outside directors & Indep & The proportion of outside (non-executive) directors on the board \\
State ownership & State & The fraction of shares held by the state institutional \\
Firm size & Size & Natural logarithm of assets \\
Business risk & Risk & Standard deviation EBIT to total assets \\
Firm leverage & Debt & Liabilities to equity ratio \\
\hline
\end{tabular}

\subsection{Analytical Approach}

To test hypotheses $\mathrm{H} 1$ and $\mathrm{H} 2$, we use a correlation analysis, regressions analysis on the three-stage of the life-cycle differences identified above on firm performance (Tobin's Q). Wintoki et al. (2012) suggest that the present values of corporate governance are influenced by past corporate performance and if this endogenous factor is ignored, the estimation may be biased (Duru et al., 2016; Roodman, 2006). To solve this endogenous problem, we use the Dynamic Data Panel model in our estimates being consistent with Roodman (2006). He thinks that if the relationship is dynamic between the present values of an explanatory variable and the historical value of the dependent variable, the regression of the fixed effect may be biased.

\section{Results}

We first examine the correlation coefficients between the explanatory variables that are not high (less than 0.8 ) and the differential magnification factor (VIF) is less than 10 so no multicollinearity phenomenon of the explanatory variables occurs in models and variables can all be used for regression analysis.

Table 2

Statistics describing variables in the research model

\begin{tabular}{lccccc}
\hline Variable & Obs & Mean & Max & Min & Std \\
\hline TobinO & 3.094 & 1.043 & 35.44 & 0.071 & 0 \\
Outside directors & 3.094 & 0.322 & 1 & 0 & 0.310 \\
CEO duality & 3.094 & 0.254 & 1 & 0.0002 & 0.436 \\
Risk & 3.094 & 0.026 & 0.788 & 0.002 & 0.039 \\
Debt & 3.094 & 0.513 & 0.967 & 0.050 & 0.182 \\
State ownership & 1.548 & 0.431 & 14.46 & 0.13 & 0.654 \\
Firm size & 3.094 & 11.81 & & & \\
\hline
\end{tabular}


Table 2 reports basic statistics, we have a full sample of 3,094 company-years. The firm performance is represented the Tobin's Q variable of an average firm of 1,043 , the average concurrent level is $25.4 \%$, the average outside directors is $32,2 \%$, the average state ownership is $43.1 \%$ and the average logarithm of companies is 11.81 .

Table 3 reports the effect of CEO duality on firm performance through the stages of the firm life-cycle. To test the suitability of the SGMM dynamic table model, Sargan or Hansen tested for the limit of overdetermination and Arellano - Bond tested for the phenomenon of level 2 autocorrelation are used. The results in Table 2 show that the 2nd-level correlation test (AR2) and Hansen test are both greater than $10 \%$ so the regression results are appropriate.

Table 3

CEO duality on firm performance through the stages of the firm life-cycle

\begin{tabular}{|c|c|c|c|}
\hline \multirow{2}{*}{ Variable } & \multicolumn{3}{|c|}{ Tobin's Q } \\
\hline & Growth Stage & Mature Stage & Decline Stage \\
\hline \multirow[t]{2}{*}{ L.TobinQ } & $0.857 * * *$ & $0.821 * * *$ & $0.920 * * *$ \\
\hline & $(0.106)$ & $(0.023)$ & $(0.047)$ \\
\hline \multirow{2}{*}{ CEO duality } & $0.524 *$ & $-0.151^{*}$ & -0.198 \\
\hline & $(0.298)$ & $(0.090)$ & $(0.178)$ \\
\hline \multirow{2}{*}{ Outside directors } & -0.457 & $-0.148^{*}$ & $-0.240 * * *$ \\
\hline & $(0.323)$ & $(0.077)$ & $(0.092)$ \\
\hline \multirow[t]{2}{*}{ State ownership } & $2.052^{* *}$ & $-0.837 * * *$ & -0.266 \\
\hline & $(0.861)$ & $(0.159)$ & $(0.334)$ \\
\hline \multirow{2}{*}{ Firm size } & $0.914 * * *$ & $0.105^{*}$ & $-0.187 * *$ \\
\hline & $(0.237)$ & $(0.057)$ & $(0.081)$ \\
\hline \multirow[t]{2}{*}{ Debt } & $4.455 * * *$ & 0.212 & 0.035 \\
\hline & $(0.723)$ & $(0.222)$ & $(0.218)$ \\
\hline \multirow[t]{2}{*}{ Risk } & $11.363^{*}$ & $6.038 * * *$ & $-2.519^{*}$ \\
\hline & $(6.257)$ & $(1.009)$ & $(1.501)$ \\
\hline \multirow[t]{2}{*}{ Const } & $-14.009^{* * *}$ & -0.789 & $2.575 * * *$ \\
\hline & $(2.931)$ & $(0.648)$ & $(0.942)$ \\
\hline AR1 & 0.0210 & 0.173 & 0.0408 \\
\hline AR2 & 0.104 & 0.625 & 0.136 \\
\hline Hansen & 0.872 & 0.576 & 0.268 \\
\hline
\end{tabular}

$* * *, * *, *$ correspond to the $1 \%, 5 \%$ and $10 \%$ significance levels.

Research results indicate that duality has a positive impact on corporate performance in the growth phase (Peng et al., 2007; Yang \& Zhao, 2014). This result confirms the H1 hypothesis and supports the view of stewardship theory, that the duality can run and supervise the firm clearly and consistently to increase the results of the firm. Besides, the research results show that state ownership brings positive value to firm performance in the growth phase, which means that during the growth period, Vietnamese companies need resources to for growth purposes, CEO duality (especially in companies with high state ownership) will bring the benefits to the firm. At the same time, the results of Table 3 demonstrate that CEO duality has negative on firm performance in the maturity stage (Cornett et al., 2008; Daily \& Dalton, 1994). This result confirms the hypothesis H2 and supports the view of the agency theory that the CEO duality will create a powerful CEO with absolute power and can lead to ineffective supervision of the board (Adams et al., 2005; Cadbury \& Cadbury, 2002). Also, the research results show that the outside directors don't bring results to the firm, this may be because the outside directors do not perform their roles and responsibilities to consulting and supervising the behavior of firm managers.

\section{Conclusion}

To examine the impact of duality on the firm performance of Vietnamese companies through the stages of the life cycle of the firm, the study used data collected from 442 companies listed on the Vietnam Stock Exchange in the period from 2012 to 2018. The main research results include: (1) The CEO duality positively affects firm performance in the growth stage of the life cycle; (2) The CEO duality negatively effect on the firm performance in the maturing stage of the life cycle; (3) Unconfirmed CEO duality effects on the firm performance in the decline stage of the life cycle. Research results with the majority of companies in the mature stage support the opinion of Decree 71/2017 / ND-CP on banning the chairman of the BOD and CEO is one person in companies listed on the Vietnam Stock Exchange. However, the author proposes to consider the case of listed companies in the growth stage of the life cycle of the firm. Besides, companies should review the process of electing outside directors' members, the criteria of outside directors members, and the performance evaluation criteria of these members because of possible members. Outside directors will not pay much attention to the performance of the task but tend to satisfy other Board 
members or show a free-rider role (Pham et al., 2020). The limitation of the study is that it has not considered some characteristics of the CEO who are likely to affect the firm performance, such as education level, gender, age, ownership rate, and nonlinear relationship between ownership ratio and firm performance. This is a suggestion for further studies.

\section{Acknowledgement}

The authors would like to thank the anonymous referees for constructive comments on earlier version of this paper.

\section{References}

Adams, R. B., Almeida, H., \& Ferreira, D. (2005). Powerful CEOs and their impact on corporate performance. The Review of Financial Studies, 18(4), 1403-1432.

Anthony, J. H., \& Ramesh, K. (1992). Association between accounting performance measures and stock prices. A test of the life cycle hypothesis. Journal of Accounting and Economics, 15(2-3), 203-227.

Bhagat, S., \& Bolton, B. (2008). Corporate governance and firm performance. Journal of Corporate Finance, 14(3), $257-273$.

Bich, N., \& Thai, P. (2019). The effects of leadership skills on firm performance: The case of textile and garment firms in Vietnam. Management Science Letters, 9(12), 2121-2130.

Cadbury, A., \& Cadbury, C. A. (2002). Corporate governance and chairmanship: A personal view. Oxford University Press on Demand.

Cornett, M. M., Marcus, A. J., \& Tehranian, H. (2008). Corporate governance and pay-for-performance: The impact of earnings management. Journal of Financial Economics, 87(2), 357-373.

Dalton, D. R., Daily, C. M., Ellstrand, A. E., \& Johnson, J. L. (1998). Meta-analytic reviews of board composition, leadership structure, and financial performance. Strategic management journal, 19(3), 269-290.

Doan, T. (2020). Financing decision and firm performance: Evidence from an emerging country. Management Science Letters, 10(4), 849-854.

Donaldson, L., \& Davis, J. H. (1991). Stewardship theory or agency theory: CEO governance and shareholder returns. Australian Journal of Management, 16(1), 49-64.

Duru, A., Iyengar, R. J., \& Zampelli, E. M. (2016). The dynamic relationship between CEO duality and firm performance: The moderating role of board independence. Journal of Business Research, 69(10), 4269-4277.

Fama, E. F., \& Jensen, M. C. (1983). Agency Problems and Residual Claims. The Journal of Law and Economics.

Jawahar, I. M., \& McLaughlin, G. L. (2001). Toward a descriptive stakeholder theory: An organizational life cycle approach. Academy of Management Review, 26(3), 397-414.

Jensen, M. C., \& Meckling, W. H. (1976). Theory of the firm: Managerial behavior, agency costs and ownership structure. Journal of Financial Economics. https://doi.org/10.1016/0304-405X(76)90026-X

Li, Y., \& Zhang, X. T. (2018). How Does Firm Life Cycle Affect Board Structure? Evidence from China's Listed Privately Owned Enterprises. Management and Organization Review, 14(2), 305-341.

Liang, C.-J., Lin, Y.-L., \& Huang, T.-T. (2011). Does Endogenously Determined Ownership Matter on Performance? Dynamic Evidence from the Emerging Taiwan Market. Emerging Markets Finance and Trade, 47(6), 120-133.

Muhammad, K., Saoula, O., Issa, M., \& Ahmed, U. (2019). Contract management and performance characteristics: An empirical and managerial implication for Indonesia. Management Science Letters, 9(8), 1289-1298.

Muth, M., \& Donaldson, L. (1998). Stewardship theory and board structure: A contingency approach. Corporate Governance: An International Review, 6(1), 5-28.

Peng, M. W., Zhang, S., \& Li, X. (2007). CEO Duality and Firm Performance during China's Institutional Transitions. Management and Organization Review, 3(2), 205-225.

Pham, Q., Ho, T., Pham, D., \& Nguyen, H. (2020). Effects of corporate governance on high growth rate: evidence from Vietnamese listed companies. Management Science Letters, 10(7), 1553-1566.

Roodman, D. (2006). How to Do xtabond2: An Introduction to Difference and System GMM in Stata. Centre for Global Development.

Singh, S., Tabassum, N., Darwish, T. K., \& Batsakis, G. (2018). Corporate Governance and Tobin's Q as a Measure of Organizational Performance. British Journal of Management, 29(1), 171-190.

Wintoki, M. B., Linck, J. S., \& Netter, J. M. (2012). Endogeneity and the dynamics of internal corporate governance. Journal of Financial Economics, 105(3), 581-606.

Yang, T., \& Zhao, S. (2014). CEO duality and firm performance: Evidence from an exogenous shock to the competitive environment. Journal of Banking and Finance. 
(C) 2020 by the authors; licensee Growing Science, Canada. This is an open access article distributed under the terms and conditions of the Creative Commons Attribution (CC-BY) license (http://creativecommons.org/licenses/by/4.0/). 